\title{
APLIKASI FUZZY LINEAR PROGRAMMING (FLP) DAN SIMULASI ARENA 10.0 UNTUK MENGOPTIMALKAN PRODUCTION PLANNING
}

\author{
Suseno $^{*}$, Ari Zaqi Al-Faritsy ${ }^{*}$ \\ Staf Pengajar Jurusan Teknik Industri Universitas Teknologi Yogyakarta \\ Jl Ringroad Utara, Jombor, Sleman, Yogyakarta Telp. (0274) 623310
}

\begin{abstract}
Abstrak
Perencanaan produksi yang dilakukan oleh PT Tonggak Ampuh Unit III Yogyakarta adalah menyederhanakan beberapa produk menjadi 2 produk yaitu tiang pancang dan tiang listrik. Mengacu pada 2 produk tersebut beserta dengan kebutuhan jenis dan jumlah materialnya serta kapasitas produksinya, selanjutnya dilakukan pembuatan model matematis berupa Linear Programming (LP) dan Fuzzy Linear Programming (FLP) dengan memaksimumkan laba.

Metodologi penelitian yang diterapkan pada kasus ini adalah hasil perhitungan optimasi menggunakan Linear Programming (LP) dan Fuzzy Linear Programming (FLP) diperoleh laba maksimum. Laba maksimum dari kedua metode tersebut dibandingkan dan dipilih yang terbesar untuk dijadikan masukkan dalam running simulasi menggunakan ARENA 10, apakah rencana produksi yang dihasilkan layak untuk dijalankan di lantai produksi atau tidak.

Model optimal perencanaan produksi dengan model FLP produksi untuk tiang listrik sebanyak 242 unit dan untuk tiang pancang sebanyak 152 unit dan keuntungan yang optimal adalah Rp 329.149.000,-.
\end{abstract}

Kata kunci : perencanaan produksi; linier programming; fuzzy linier programming; simulasi; arena

\begin{abstract}
Production planning conducted by PT. Tonggak Ampuh Unit III of Yogyakarta is simplifying some of the product into two products namely poles and power lines. Two refers to the product along with the needs of the type and quantity of material and production capacity, then performed the mathematical modeling of a Linear Programming (LP) and Fuzzy Linear Programming ( FLP ) to maximize profits .

The research methodology applied in this case is the result of the optimization calculations using Linear Programming (LP) and Fuzzy Linear Programming (FLP) obtained the maximum profit. The maximum profit from both methods were compared and selected the largest to be entered in running simulation using ARENA 10, if feasible production plan is generated to run on the production floor or not .

Optimal production planning model with a model for the production of electric pole FLP many as 242 units and to pile as many as 152 units and the optimal profit is Rp. 329.149.000,-.
\end{abstract}

Keyword : production planning; linier programming; fuzzy linier programming; simulation, arena

\section{Pendahuluan}

Perencanaan produksi Production Planning perusahaan dapat dilakukan dengan berbagai cara. Pada PT Tonggak Ampuh Unit III Yogyakarta sebagai produsen penghasil berbagai produk tiang listrik dan tiang pancang. Perencanaan produksinya dilakukan dengan cara analisis kuantitatif sebagai alat bantu pengambilan keputusan., karena perusahaan memiliki tingkat kompleksitas cukup tinggi, dimana terdapat multi produk dan multi periode.

Penggunaan model analitik (analisa kuantitatif) misalnya dengan Linear Programming (LP) dan Fuzzy

\footnotetext{
${ }^{*}$ Penulis Korespondensi.

email: onesuseno@gmail.com, zaqi.alfaritsy@gmail.com
}

Linear Programming (FLP) pada permasalahan perencanaan produksi dapat dilakukan dengan baik apabila beberapa asumsi dasarnya terpenuhi dalam kondisi aktual. Model analitik memberikan solusi optimal perencanaan produksi. Namun demikian seringkali tidak mudah atau tidak layak untuk dilaksanakan dalam kondisi aktualnya, karena beberapa asumsi tidak bisa dipenuhi dalam kondisi riil perusahaan, misalnya : waktu proses produksi yang stokastik, waktu kedatangan bahan baku yang probabilistik, transfer time dan sebagainya. Penggunaan model simulasi dapat menutupi dan menyelesaikan kekurangan model analitik tersebut, dimana dengan model simulasi dapat meniru proses produksi nyata, meskipun tidak memberikan solusi optimal. Maka pada penelitian ini dicoba untuk menggabungkan 2 model 
tersebut, atau sering disebut sebagai metode hybrid (Hybrid Method). Dengan demikian diharapkan hasil perencanaan produksinya dapat dilakukan dalam kondisi optimal sekaligus layak untuk dijalankan.

Permasalahan yang dihadapi oleh PT Tonggak Ampuh Unit III Yogyakarta adalah perencanaan produksi yang telah dibuat dengan asumsi data yang deterministik, ternyata seringkali belum bisa diperoleh hasil yang optimal sekaligus layak untuk diproduksi. Oleh karena itu pada penelitian ini akan dibahas bagaimana perencanaan produksi dibuat secara optimal sesuai dengan tujuan perusahaan, namun dapat dilaksanakan dengan baik oleh perusahaan.

\section{Metode Penelitian}

Secara ringkas, metodologi penelitian yang digunakan dalam penyelesaian masalah ini dapat terlihat pada gambar 1 .

\section{Hasil Dan Pembahasan}

Dari hasil menentukan fungsi tujuan dan menentukan fungsi kendala yang ada pada PT. Tonggak Ampuh Unit III Yogyakarta di atas dapat diketahui formulasi yang digunakan untuk LP dan FLP adalah sebagai berikut: maksimumkan :
$\mathrm{Z}=950.000 \mathrm{X}_{1}+650.000 X_{2}$

dengan batasan

$9,3 x_{1}+2,93 x_{z} \leq 3300+99 \mathrm{t}$

$72 x_{2}+45 x_{z} \leq 24000+720 \mathrm{t}$

$108 x_{2}+68 x_{2} \leq 36000+1080 \mathrm{t}$

$162 x_{2}+102 x_{z} \leq 55000+1650 \mathrm{t}$

$0,1 x_{2}+0,1167 x_{1} \leq 42$

$x_{1}, x_{2} \geq 0$

Keterangan :

$\mathrm{Z}=$ Keuntungan/laba per unit produk

$X_{1}=$ Produk tiang listrik

$X_{2}=$ Produk tiang pancang

Menyelesaikan permasalahan dan persamaan fungsi dengan menggunakan software win qsb. Langkah pertama yaitu memasukan data model batasan $t=0$ ke dalam program win $q \mathrm{sb}$, sehingga dapat diketahui dari hasil perhitungan untuk $\mathrm{t}=0$.

Solusi optimal diperoleh dengan memproduksi sebanyak 233 batang tiang listrik dan 159 batang tiang pancang, sehingga laba perusahaan menjadi Rp 324.700.000,-. Untuk penggunaan materialnya adalah sebagai berikut: PC wire 2.632,77 kg, semen $23.931 \mathrm{~kg}$, pasir $35.976 \mathrm{~kg}$ dan split $53.964 \mathrm{~kg}$; sedangkan total waktu yang dibutuhkan untuk produksi sebesar 41,8553 jam.

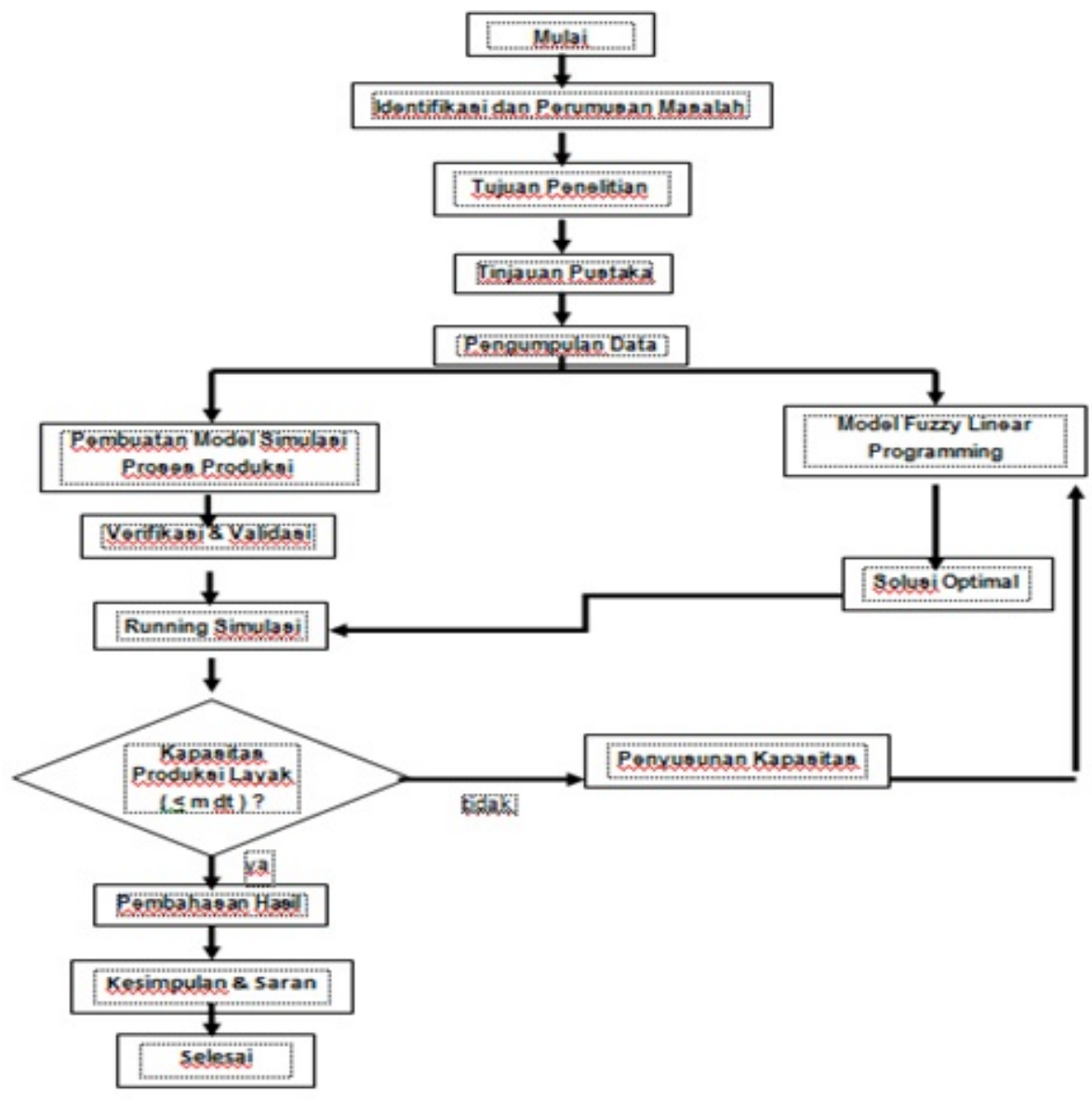

Gambar 1. Diagram alir penelitian 
Mencari model batasan linear programming $\mathrm{t}=1$ akan menambahkan toleransi penambahan bahan baku yang masih bisa disediakan perusahaan pada formulasi kendala batasan untuk mengetahui keuntungan dan produksi yang harus diproduksi untuk tiang listrik dan tiang pancang. Sehingga untuk hasilnya akan seperti batasan di bawah ini:

Untuk $\mathrm{t}=1(\lambda=0)$, diperoleh model mak:

$\mathrm{Z}=950.000_{X_{*}}+650.000 X_{2}$ dengan batasan :

$9,3+2,93 \leq 3399$

$72+45 \leq 24720$

$108+68 \leq 37080$

$162+102 \leq 56650$

$0,1+0,1167 \leq 42, \geq 0$

Menyelesaikan permasalahan dan persamaan fungsi dengan menggunakan software win qsb yaitu memasukan data model batasan $\mathrm{t}=1$ ke dalam program win qsb, sehingga di dapat hasil dari hasil perhitungan di ketahui solusi untuk $\mathrm{t}=1$.

Solusi optimal diperoleh dengan memproduksi sebanyak 253 batang tiang listrik dan 143 batang tiang pancang, sehingga laba perusahaan menjadi Rp 333.300.000,-. Untuk penggunaan materialnya adalah sebagai berikut: PC wire $2.771,89 \mathrm{~kg}$, semen $24.651 \mathrm{~kg}$, pasir $37.048 \mathrm{~kg}$ dan split $55.572 \mathrm{~kg}$; sedangkan total waktu dibutuhkan untuk produksi sebesar 41,9881 jam.

Setelah didapat hasil $\mathrm{p}_{0}$ (t1-t0) dapat dibentuk model fuzzy linear programming. Dari kedua hasil ( $\mathrm{t}=0$ dan $\mathrm{t}=1$ ) dapat ditentukan nilai $\mathrm{p}_{0}$, yaitu hasil pengurangan dari $\mathrm{z}$ pada saat $\mathrm{t}=1$ dengan $\mathrm{z}$ pada saat $\mathrm{t}=0$ $\left(\mathrm{p}_{0}=333.300 .000-324.700 .000=8.600 .000\right)$. Setelah didapat hasil $\mathrm{p}_{0}$ (t1-t0) dapat dibentuk model FLP. Model Batasan FLP ini digunakan dikarenakan hasil dari model batasan $\mathrm{t}=1$ yang mempertimbangkan jika toleransi bahan baku maksimal yang masih bisa diberikan oleh perusahaan perminggu untuk produksi produk tiang listrik dan tiang pancang di gunakan hasilnya kurang optimal. Pada FLP akan dicari suatu nilai $\mathrm{z}$ yang merupakan fungsi objektif yang akan di optimasikan. sedemikian hingga tunduk pada batasanbatasan yang dimodelkan dengan menggunakan himpunan fuzzy sebagai berikut:

maksimumkan : $\lambda$ membuat batasan untuk FLP.

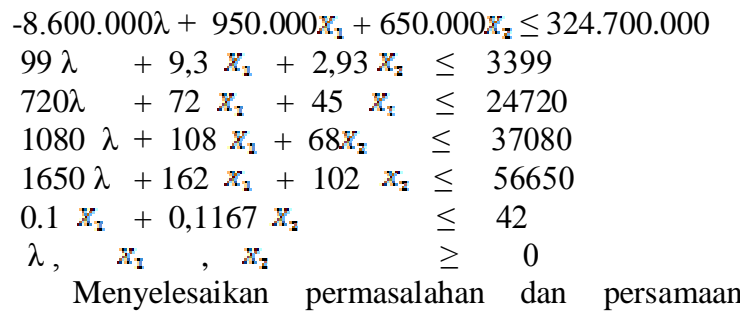
fungsi FLP dengan menggunakan software win qsb. Langkah pertama yaitu memasukan data model FLP ke dalam program win qsb, sehingga di dapat hasil dari hasil perhitungan di ketahui solusi untuk FLP.

Solusi optimal diperoleh dengan memproduksi sebanyak 242 batang tiang listrik dan 152 batang tiang pancang, sehingga laba perusahaan menjadi Rp 329.149.000,- pada tingkat lamda $=0.5173$.Untuk penggunaan materialnya adalah sebagai berikut: PC wire $2.750,551 \mathrm{~kg}$, semen $24.669,23 \mathrm{~kg}$, pasir $37.080 \mathrm{~kg}$ dan split $55.635,52 \mathrm{~kg}$; sedangkan total waktu yang dibutuhkan untuk produksi sebesar 42 jam. Sehingga dengan model FLP produksi untuk tiang listrik sebanyak 242 dan untuk tiang pancang sebanyak 152 dan keuntungan yang optimal adalah Rp 329.149.000,-. Dengan catatan bahwa pada kondisi ini membutuhkan pc wire sebanyak $2.695,95 \mathrm{~kg}$, semen sebanyak 24.264 $\mathrm{kg}$, pasir sebanyak $36.472 \mathrm{~kg}$ dan split sebanyak 54.708 $\mathrm{kg}$, jam proses produksi selama 41,9384 menit. Sehingga dari hasil ini mengharuskan perusahaan untuk menambah semen sebanyak $264 \mathrm{~kg}$ dari $24.000 \mathrm{~kg}$ yang mutlak harus disediakan dan menambah pasir sebanyak $472 \mathrm{~kg}$ dari $36.000 \mathrm{~kg}$ yang mutlak disediakan.

Simulasi proses produksi ini akan diuraikan dalam beberapa bagian, yaitu : input simulasi, verifikasi \& validasi model simulasi, dan analisis kelayakan perencanaan produksi. Input simulasi meliputi distribusi waktu kedatangan bahan dan jam mesin. Untuk waktu kedatangan bahan terkait proses sebelumnya serta jam mesin/waktu yang digunakan untuk proses selanjutnya dilakukan uji verifikasi dan dinyatakan sesuai oleh perusahaan. Tahapan selanjutnya adalah dilakukan uji validasi. Uji validasi dilakukan dengan membandingkan sistem riil dengan model simulasi yang dibuat. Apakah desain model simulasi bisa diterima sebagai perwakilan sistem riil atau tidak. Uji validasi dilakukan dengan menggunakan $\mathrm{T}$ test pada tabel 1. Dan uji validasi model dengan menggunakan software SPSS versi 18 , proses uji menggunakan uji $\mathrm{T}$ satu sampel. Hasil uji validasi disajikan pada tabel 2 .

Tabel 1. Uji validasi model simulasi proses produksi tiang listrik

\begin{tabular}{c|c|c|c|c|c|c|c|c|c}
\multirow{2}{*}{ Produk } & Jumlah & \multicolumn{7}{c}{ Hasil simulasi 8 kali (replikasi dalam jam) } \\
\cline { 2 - 8 } & & 1 & 2 & 3 & 4 & 5 & 6 & 7 & 8 \\
\hline Tiang & 420 & 42,00 & 42,00 & 42,00 & 42,00 & 42,00 & 42,10 & 42,10 & 42,10 \\
listrik & One sample T : Validasi \\
\hline \multicolumn{1}{c}{ Test of mu $=42$ vs mu not 42} \\
\hline
\end{tabular}

Tabel 2. Hasil validasi proses tiang listrik

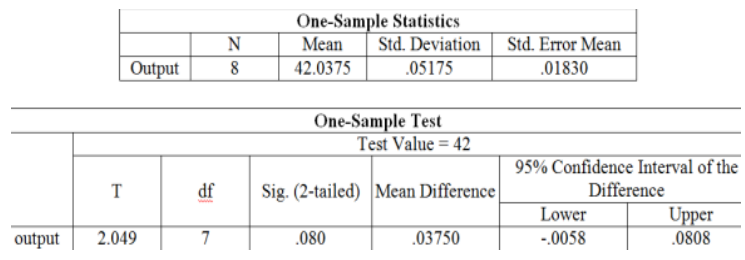

Tabel 3. Uji validasi model simulasi proses produksi tiang pancang

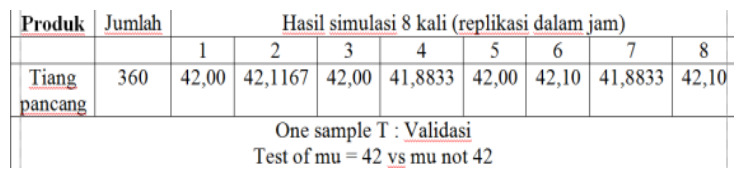

Uji validasi model dengan menggunakan software SPSS versi 18, proses uji menggunakan uji $\mathrm{T}$ satu sampel. Hasil uji validasi disajikan pada tabel 4 
Tabel 4. Hasil validasi proses tiang pancang

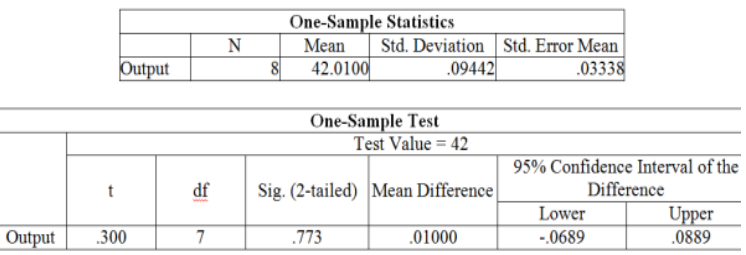

Pada tabel 2 dan 4 menunjukkan bahwa nilai sig. (2-tailed) > nilai signifikansi $(0,05)$, maka sistem simulasi sama dengan sistem nyata.

Setelah model simulasi memenuhi dan sesuai kondisi riilnya, berdasarkan uji verifikasi dan validasi, maka model simulasi yang dibuat dikatakan relevan dengan kondisi riilnya. Hasil running simulasi perencanaan produksi dilakukan 4 kali

Tabel 5. Cycle Time tiap Produk (4 kali replikasi)

\begin{tabular}{c|c|r|r|r|r}
\hline Kode & Produk & \multicolumn{3}{|c}{ Cycle Time (Replikasi 4 Kali) } \\
\hline 1 & Tiang listrik & 24,20 & 24,30 & 24,30 & 24 \\
\hline 2 & Tiang pancang & 17,7384 & 17,8550 & 17,7384 & 17,8550 \\
\hline \multicolumn{2}{c|}{ Jumlah } & 41,9384 & 42,155 & 42,0384 & 41.855 \\
\hline
\end{tabular}

Uji validasi model dengan menggunakan software SPSS versi 18, proses uji menggunakan uji $\mathrm{T}$ satu sampel. Hasil uji validasi disajikan pada tabel 6

Tabel 6. Validasi running solusi FLP

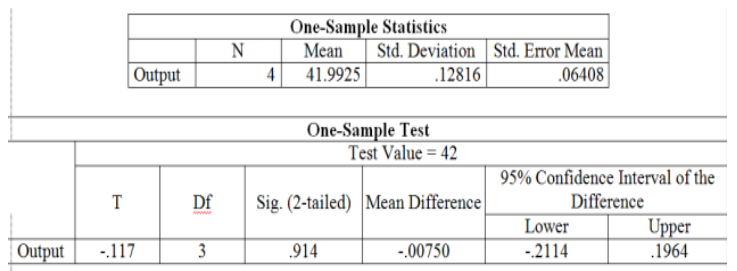

Pada tabel di atas menunjukkan bahwa nilai sig. (2-tailed) > nilai signifikansi $(0,05)$, maka sistem simulasi sama dengan sistem nyata.

\section{Kesimpulan}

Berdasarkan penelitian yang telah dilakukan di PT. Tonggak Ampuh Unit III Yogyakarta dapat diambil kesimpulan bahwa Model optimal perencanaan produksi dengan model FLP produksi untuk tiang listrik sebanyak 242 unit dan untuk tiang pancang sebanyak 152 unit dan keuntungan yang optimal adalah Rp 329.149.000,-.

Model sistem simulasi menghasilkan rata - rata produk tiang listrik sebanyak 42,03 unit dan sistem nyata 42 unit menghasilkan nilai sig. (2-tailed) $(0,080)>$ nilai signifikansi $(0,05)$ dan rata - rata tiang pancang sebanyak 42,01 unit dan sistem nyata 42 unit menghasilkan nilai sig. (2-tailed) $(0,773)>$ nilai signifikansi $(0,05)$, sehingga model simulasi sesuai dengan kondisi riilnya (sistem nyata).
Hasil uji verifikasi dan validasi dengan nilai rata rata waktu simulasi sebesar 41,99 menit dan nilai rata rata waktu nyata sebesar 42 menit menghasilkan nilai sig. (2-tailed) $(0,914)>$ nilai signifikansi $(0,05)$, sehingga waktu proses produksi (cycle time) dinyatakan layak.

\section{Daftar Pustaka}

Byrne, MD., \& M.A. Bakir, 1999. Production Planning Using a Hybrid Simulation - Analytical Approach,. International Journal of production Economics vol. 59, p $305-311$.

Czarnecki, H.. Bernard, J. Schroer \& M Mizzanur Rahman,. 1997. Using Simulation to Schedule Manufacturing Resources. Proceedings of the 1997. Winter Simulation Conference, p.750 - 757.

Kelton, W. David, Sadowski, Randall P. \& Sadowski, Deborah A., 2002. Simulation with Arena, Mc. Graw-Hill Companies Inc, ${ }^{2}$ nd Edition, New York.

Kusumadewi, Sri dan Purnomo, Hari., 2010. Aplikasi Logika Fuzzy untuk Pendukung Keputusan, Graha Ilmu, Yogyakarta.

Kusumadewi, Sri; Hartati, Sri; Harjoko, Agus dan Wardoyo, Retantyo, 2006, Fuzzy Multi Attribute decision Making, Graha Ilmu, Yogyakarta

Law, A.M., \& Michael G. Mc Gomas, 1997. Simulation of Manufacturing systems. Proceeding of the 1997. Winter Simulation Conference, p.86 - 89.

Mulyono, Joko, 2001. Perencanaan Produksi Menggunakan Gabungan Model Simulasi dan Pendekatan Analitik, Tesis PS. Teknik Industri, Institut Teknologi Sepuluh November, Surabaya.

Puji E., Ayudina., 2002. "Jurnal Penerapan Metode Linear Programming untuk Membuat Perencanaan Produksi yang Optimal'. Skripsi. Malang : Universitas Muhammadiyah.

Purwantoro, Nanang Agus, 2003. Perencanaan Produksi Menggunakan Gabungan Model Simulasi dan Pendekatan Analitik, Tesis Program Studi Teknik Industri, Institut Teknologi Sepuluh November, Surabaya.

Sartin, 2012, Penerapan Fuzzy Multi Objective Linear Programming pada Perencanaan Agregat Produksi, Prosiding Seminar Nasional Aplikasi Sains \& Teknologi (SNAST) Periode III, Yogyakarta

Siringoringo, Hotniar., 2005. Seri Teknik Riset Operasional. Pemrograman Linear , Penerbit Graha Ilmu, Yogyakarta.

Siswanto, 2007, Operations Research, Erlangga, Jakarta. Taha, Hamdy A., 1996, Riset Operasi, Binarupa Aksara, Jakarta.

Safi, M. R.; Maleki, H. R; And Zaeimazad, E.; 2007, A Note On The Zimmermann Method For Solving Fuzzy Linear Programming Problems, Iranian Journal of Fuzzy Systems Vol. 4, No. 2, (2007) pp. 31-45, Iran.

Yutmiati, Wiwin, 2008, Aplikasi Fuzzy Linear Progamming (FLP) Untuk Perencanaan Hasil Produksi (Studi Kasus CV. GIZA Bojonegoro), Skripsi, UIN, Malang. 